膜 (MEMBRANE), 26 (3) , 158-161（2001）

製品＆技術

\title{
中空糸型限外万過膜除濁装置
}

\author{
宮崎泰光・阿瀬智暢 \\ ダイセン・メンブレン・システムズ株式会社 メンブレン営業部 \\ テ160-0022 東京都新宿区新宿 $1-34-15$
}

\section{Compact Water Purification Unit System by Ultrafiltration Hollow Fibers}

\author{
Yasumitsu Miyazaki and Tomonobu Ase \\ DAICEN MEMBRANE-SYSTEMS LTD. \\ 1-34-15 Shinjuku, Shinjuku-ku, Tokyo 160-0022, Japan
}

\begin{abstract}
Compact unit system is commercially provided for cut treatment of turbidity and bacteria in water from general source. Equipping with newly developed high performance hollow fiber ultrafiltration ( UF ) membrane in this system, compact system design can be succeeded to obtain high water quality and very stable operation in long term only with periodical back washing of the hollow fibers. Cellulose Acetate is selected as a membrane material of the hollow fiber in order to give the fiber anti-membrane fauling and easy cleaning natures because of its hydrophilicity. Furthermore high membrane water flux performs well not only on the water production but also on the effective back washing by asymmetric membrane structure designed very highly. This unit system is expected economically benefit from applying to the small and middle classed water purification market.
\end{abstract}

Key words:ultrafiltration/purification/ unit system

\section{1. はじめに}

ここ数年膜による上水処理が小規模施設から普 及してきているが，北海道西空知の $6000 \mathrm{~m}^{3} /$ 日の 実稼働，栃木県今市市の $14,000 \mathrm{~m}^{3} /$ 日の工事開始 などいよいよ大型施設へも普及が始まった。従来 の凝集沈殿砂乃過法は, 原水の濁度変化に対応し づらく熟練した管理者が必要であり，降雨時等の 対応は困難であった, 完全自動化が図れ透過水濁 度が安定している膜法は今後大きく普及すると考 えられる。
膜法が大きく普及していくためには, 膜装置の コストダウンが求められる。これは，今後普及さ れる民需水処理分野でも求められている。そこで, 上水処理で多くの実績がある酢酸七ルロース中空 系膜を用いた小規模限外万過膜除濁装置「MOL S E P S U F システム」システムを開発・商品 化した。 
膜（MEMBRANE），Vol. 26 No.3（2001） 159

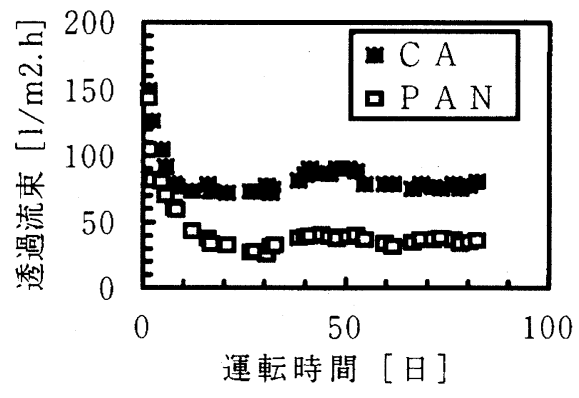

Fig.1 中空系膜材質の透過流速

\section{U F 除濁装置の特長}

除濁用膜は，長期間安定したろ過性能が要求さ れる。酢酸セルロース ( C A ) 中空糸膜は，一般 的な中空糸膜材質ポリアクリロニトリル $(\mathrm{P} \mathrm{A} \mathrm{N})$ と比べ 2 倍以上のろ過速度を得ることができる (Fig.1).

運動初期は, 両膜素材に差はないが, 時間の経 過とともに差がつく。これは, 酢酸セルロースが 濁質分の付着が少なく，また逆洗によって剥がれ やすいためである。このため, 必要な膜面積が小 さくなり，その結果ポンプ・配管等も小型化でき 装置全体がコンパクトになる。酢酸セルロース中 空糸膜は 15 万分画の限外万過 (UF) 膜であり, ウイルスまで除去でき高品質な浄水処理ができ る.

\section{3. 高フラックス中空糸膜の開発}

酢酸セルロース中空系膜は, 他の材質の中空糸 膜よりも高い透過流束が得られるが, 今後広く普 及させていくためにも透過流束を更に向上させた 高フラックス化膜を開発した。これは「透水性能 を増加させるために」中空糸膜のスキン層付近の 空孔率を増加させたものである. 高フラックス化

Table.1 膜抵抗比較

\begin{tabular}{|l|c|}
\hline & 膜抵抗 \\
\hline 従来膜 & $4.6 \times 10^{11}\left[\mathrm{~m}^{-1}\right]$ \\
\hline 高フラックス化膜 & $14.1 \times 10^{11}\left[\mathrm{~m}^{-1}\right]$ \\
\hline
\end{tabular}

膜と従来膜の膜抵抗值をTable. 1 に比較した.

一般的に，膜抵抗を小さくしても透過流束はほ とんど増加しないことが知られているが，膜抵抗 を小さくすることで逆洗時の透過線速が大きくな り, 膜の洗浄効果を高めることができる。兵庫県 の河川水を用い実液ろ過運転を行ったが，高フラ ックス膜は従来膜の約 2 倍の透過流速を長期間維 持できることを確認した。

この高フラックス膜を使用することにより，よ り少ない電力でさらにコンパクトな装置にするこ とができた。

\section{4. 装置の詳細}

Fig.2 に膜処理システムフローを示す。膜処理 システムは, 内圧型クロスフローろ過システムで あり，定期的に自動逆洗を行う。配管材質は，P V C とステンレスの 2 種類がある. 原水に応じて 前処理の必要性がある. 河川水や工業用水などの 場合は, $200 \mu \mathrm{m}$ 程度のオートストレーナで十分 である，地下水は，水質によって除鉄・除マンガ ン・活性炭などの設置が必要である。

本システムに使用する酢酸セルロース中空系膜 モジュールは, 河川水や井水のろ過に数多くの実 績がある。原水の水質により多少増減があるが, 本システムでは一般的な河川水を原水に想定し平 均透過流速は $1.8 \mathrm{~m} / \mathrm{d}$ を設定している.

透過流量は, 透過出口の定流量弁で一定にして いるが，オプションとして流量センサーからの信 号で循環ポンプのインバー夕制御させることも可 能である。膜モジュール内への循環速度は, $0.1 \mathrm{~m} / \mathrm{s} \sim 0.2 \mathrm{~m} / \mathrm{s}$ を標準としている.

また，全量ろ過運転も，原水水質が清浄であれ ば十分可能である。

ろ過水は，はじめに逆洗タンクを満水にし，そ の後ろ過水タンクやユースポイントへ供給され る. 逆洗は，原水水質によって $30 \sim 60$ 分間隔に 1 回の割合で, 30〜60秒間膜モジュールの上から下, 下から上へ（上下逆洗）行われる。逆流水流は透 過流量の 4 倍以上の流量とし, 回収率を $90 \%$ 前後 に設定する。 
Table.2 除濁装置標準仕様（カートリッジ式中空糸夕イプ）

\begin{tabular}{|l|c|c|c|c|c|c|}
\hline 型式 & SUF-101N & SUF-102N & SUF-104N & SUF-106N & SUF-108N & SUF-110N \\
\hline 標準透過水量 $\left[\mathrm{m}^{3} / \mathrm{hr}\right]$ & 1.2 & 2.4 & 4.8 & 7.2 & 9.6 & 12 \\
\hline 限外ろ過膜 & \multicolumn{6}{|l|}{ FN20-FUC1582（酰酸セルロース, 15万分画, 16m2) } \\
\hline 最高使用温度 & \multicolumn{6}{|c|}{$40^{\circ} \mathrm{C}$ 以下 } \\
\hline モジュール本数 & 1 & 2 & 4 & 6 & 8 & 10 \\
\hline 装備機器 & \multicolumn{6}{|l|}{ 循環・逆洗ポンプ, 逆洗用タンク, 薬ユニット, 圧力計, 流量計, 他 } \\
\hline 電 源 & 200V 0.4KW & 200V 1.5KW & 200V 2.2KW & 200V 3.7KW & 200V 5.5KW & 200V 5.5KW \\
\hline
\end{tabular}
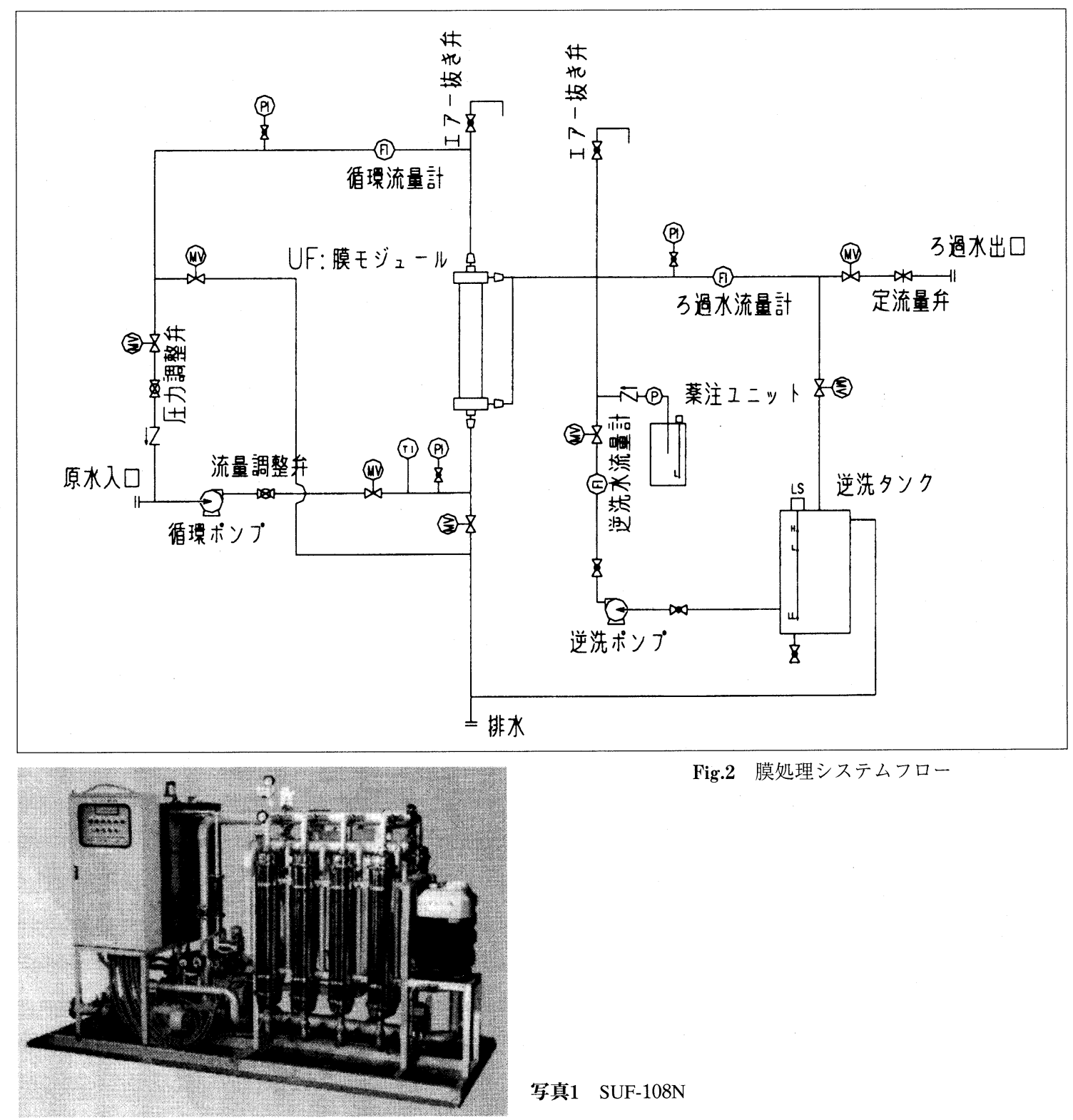

Fig.2 膜処理システムフロー 
その際, 殺菌と洗浄効果を高めるために, 逆洗 水中の残留塩素濃度が $3 \sim 5 \mathrm{ppm}$ となるように次 亜塩素酸ナトリウムを添加する。なお，エアース クラビングや凝集剤の添加は必要としない.

Table.2 にカートリッジ式中空系限外万過膜を 搭載した標準仕様を記す。ステンレスフレームで コンパクトにまとめられた装置は, 従来法の凝集 沈殿と比べ50～70\%の省スペースとなる.

写真 1 はSUF-108Nである。（長さ1300×幅 $1300 \times$ 高さ2000）パッケージ化された装置は, 設 置時間が大幅に短縮でき, 屋外仕様にも対処して いる.

\section{5. おわりに}

以上に述べた限外万過膜除濁装置は, 今後食品 業界など幅広い分野で簡便に使用できるようにパ ッケージ化したものであり, 浄水処理だけでなく, 排水処理にも適用が可能である.

更にコストダウンを追求するために大型タンク に多数の膜モジュールを収納させた集合型モジュ ールも開発中であり, 今後大規模の用水処理に限 外膜を広く普及させていきたい.

（受付日2001年1月20日 掲載決定3月20日） 